\title{
Standardy postępowania administracyjnego według ReNEUAL Modelu kodeksu postępowania administracyjnego Unii Europejskiej
}

\section{Projekt zasad modelowych postępowania administracyjnego Unii Europejskiej}

Zjawisko polegające na ujednolicaniu rozwiązań prawnych i administracyjnych zarówno w przestrzeni prawnej i organizacyjnej Unii, jak i w państwach członkowskich już od wielu lat jest przedmiotem rozważań doktryny europejskiego prawa administracyjnego. Dzięki wspólnym przedsięwzięciom badawczym europejskiej nauki prawa administracyjnego konwergencji ulegają standardy prawnoadministracyjne, wyrażające się m.in. poprzez obowiązywanie w państwach członkowskich Unii Europejskiej jednolitych zasad prawa.

Dziełem wspólnym doktryny prawa administracyjnego państw członkowskich Unii Europejskiej jest powstały przed kilkoma laty ReNEUAL Model kodeksu postępowania administracyjnego Unii Europejskiej, opracowany przez Grupę Naukowo-Badawczą ds. Prawa Administracyjnego Unii Europejskiej (ang. Research Network on EU Administrative Law) ${ }^{2}$. Celem stworzenia tego projektu nie było ani zastąpienie istniejących szczególnych przepisów regulujących postępowanie administracyjne przed organami Unii, ani zakazanie prawodawcy unijnemu uchwalania nowych szczególnych przepisów regulujących postępowanie administracyjne. Model kodeksu nie został opracowany tylko z myślą o wyznaczeniu minimalnych standardów, lecz miał on na celu przedstawienie najlepszych

1 Dr hab. Przemysław Ostojski, prof. WSZiB, Wyższa Szkoła Zarządzania i Bankowości w Poznaniu.

2 Określany dalej w skrócie jako: „ReNEUAL”, „Model” albo „projekt”. Internetowa wersja Modelu w języku angielskim ukazała się w 2014 r. pod adresem: http://www. reneual.eu. Polskie tłumaczenie ukazało się w wersji drukowanej: M. Wierzbowski, H.C. Hofmann, J.-P. Schneider, J. Ziller, J.-B. Auby, P. Craig, D. Curtin, G. della Cananea, D.-U. Galetta, J. Mendes, O. Mir, U. Stelkens, ReNEUAL Model kodeksu postępowania administracyjnego Unii Europejskiej, H.C.H. Hofmann, O. Mir, J.-P. Schneider, J. Ziller (red.), Warszawa 2015. 
praktycznych rozwiązań ${ }^{3}$. Zabiegi na rzecz stworzenia wspólnego Modelu kodeksu postępowania administracyjnego Unii Europejskiej spotkały się z przychylnością i wsparciem praktyki, tzn. sędziów najwyższych sądów unijnych, którzy podjęli się współpracy w tym zakresie z doktryną praw administracyjnego państw członkowskich ${ }^{4}$.

Projekt ReNEUAL składa się z sześciu ksiąg, obejmujących - prócz przepisów ogólnych - wydanie przepisów przez organy administracji, wydanie decyzji w sprawach indywidualnych, umowy, wzajemną pomoc oraz administracyjne zarządzanie informacjami. Przepis art. I-4 ust. 2 ReNEUAL definiuje postępowanie administracyjne jako proces, w którym organ administracji publicznej przygotowuje i formułuje czynność administracyjną w rozumieniu ust. 1 lit. a-c, tzn. prawnie wiążący akt o charakterze nieustawodawczym o zasięgu ogólnym w rozumieniu księgi II albo decyzję w rozumieniu Księgi III, albo umowę w rozumieniu Księgi IV. Decyzja oznacza zaś czynność administracyjną skierowaną do jednej lub więcej skonkretyzowanych osób publicznych albo prywatnych, wydana jest jednostronnie przez organ administracji UE lub organ administracji państwa członkowskiego $\mathrm{w}$ celu rozstrzygnięcia $\mathrm{w}$ prawnie wiążący sposób jednej lub więcej konkretnych spraw (art. III-2 ust. 1 Księgi III). Zasady i reguły zawarte w ReNEUAL nie zmierzają do wyeliminowania specyficznych uregulowań sektorowych UE, które posiadałyby - w przypadku przekształcenia projektu w akt powszechnie obowiązujący - charakter legis specialis. Przepisy te powinny być interpretowane $\mathrm{w}$ świetle zasad modelowych ${ }^{5}$.

W literaturze wskazuje się na znaczenie (istotę) stworzenia Modelu w trzech najważniejszych płaszczyznach: kodyfikacyjnej, legitymującej (do podejmowania działań władczych) oraz kulturowej $j^{6}$. W pierwszej z nich projekt gromadzi, systematyzuje i eryguje wspólne zasady prawnych form działania administracji Unii. Innowacyjność kodyfikacji Modelu polega na zebraniu w nowym akcie prawnym wszystkich istniejących zasad i reguł dotyczących wskazanej złożonej problematyki rozproszonych w licznych kodeksach, regulacjach prawnym oraz orzecznictwie sądowym, a także na modyfikowaniu istniejących zasad i reguł, jeśli zachodzi taka potrzeba, oraz na dodawaniu nowych? ${ }^{7}$ W drugiej płaszczyźnie Model ma uzupełnić

3 J.-P. Schneider, The ReNEUAL Codification Project - Book III [w:] The Model Rules on EU Administrative Procedures: Adjucation, M. Ruffert (ed.), Groningen 2016, s. 2 i n.

4 V. Skouris, Der Musterentwurf eines EU-Verwaltungsverfahrensgesetzes aus der Sicht des Europäischen Gerichtshofs, „Deutsches Verwaltungsblatt” 2016, H. 4, s. 201.

5 P. Craig, G. della Cananea, O. Mir, J.-P. Schneider, V.M. Tünsmeyer, M. Wierzbowski [w:] ReNEUAL. Model kodeksu..., s. 72.

6 K. Rennert, ReNEUAL-Musterentwurf für ein EU-Verwaltungsverfahrensrecht aus der Sicht des BVerwG, „Deutsches Verwaltungsblatt” 2016, H. 2, s. 69-70.

7 P. Craig, D. Curtin, G. della Cananea, H.C.H. Hofmann, O. Mir, J.-P. Schneider, M. Wierzbowski, J. Ziller [w:] ReNEUAL. Model kodeksu..., s. 4. 
(umocnić, utrwalić) legitymację prawną do działania organów unijnych (zwłaszcza różnych agencji unijnych). Wreszcie trzecia płaszczyzna, w obrębie której Model posiada bezprecedensową wartość, dotyczy wymiany myśli prawno-administracyjnej państw członkowskich, innowacyjności szeregu zaproponowanych $\mathrm{w}$ projekcie rozwiązań prawnych zakorzenionych $\mathrm{w}$ tradycjach prawnych poszczególnych państw, a przez to „dwukierunkowego" rozwoju prawnego - systemów narodowych oraz prawa unijnego - w omawianym obszarze ${ }^{8}$. Finalnie w doktrynie mówi się o dalszym kształtowaniu i rozwoju europejskiej kultury prawnej', której fundament zakłada ochronę podstawowych praw jednostki ${ }^{10}$.

Przedmiotem rozważań w niniejszym opracowaniu jest analiza instytucji procesowych zawartych w Księdze III - a w niezbędnym zakresie również w Księdze I - ReNEUAL Modelu kodeksu postępowania administracyjnego Unii Europejskiej. Celem analizy będzie ukazanie minimalnych standardów postępowania administracyjnego w państwach członkowskich UE. Standardy te zostaną zobrazowane według kryteriów składających się na pojęcie sprawiedliwości proceduralnej formułowane $\mathrm{w}$ aktach prawa europejskiego.

\section{Sprawiedliwość proceduralna jako expressum standardów postępowania}

Komitet Ministrów Rady Europy, wskazując w rezolucji nr (77) 31 o ochronie jednostki przed działaniami (aktami) organów administracji ${ }^{11}$ na standardy, jakie powinny obowiązywać w tych relacjach, posłużył się słowem fairness, obejmującym prawa i obowiązki, które państwa członkowskie powinny gwarantować w krajowych regulacjach postępowania administracyjnego, a które następnie znalazły wyraz w Kodeksie dobrej administracji ${ }^{12}$. $\mathrm{Z}$ kolei prawodawca unijny posługuje się słowem fairly, stanowiąc w art. 41 ust. 1 Karty praw podstawowych ${ }^{13}$, że każdy ma prawo do bezstronnego

8 K. Rennert, ReNEUAL-Musterentwurf..., s. 70.

9 A. Meuwese, Y. Schuurmans, W. Voermans, Towards a European Administrative Act, „Review of European Administrative Law” 2009, no. 2, s. 3 i n.

10 S. Walkila, Horizontal Effect of Fundamental Rights in EU Law, Groningen 2016, s. 15.

11 Rezolution (77) 31 on the protection of the individual in relation to the acts of administrative authorities, adopted by the Committee of Ministers on 28 September 1977, Council of Europe, „Information Bulletin on legal activities”, June 1978, s. 45.

12 Załącznik do rekomendacji CM/Rec(2007)7 of the Committe of Ministers to member states on good administration on 20 Juni 2007 - „Code of good administration”. Zob. Z. Kmieciak, Posteppowanie administracyjne i sqdowoadministracyjne a prawo europejskie, Warszawa 2010, s. 64 i n.; G. Krawiec, Europejskie prawo administracyjne, Warszawa 2009, s. 32; I. Kawka, Gospodarcza działalność ustugowa w prawie polskim w świetle unijnych swobód przedsiębiorczości i świadczenia usług, Warszawa 2015, s. 118 i n.

13 Karta praw podstawowych Unii Europejskiej, Dz.Urz. UE z 2016 r. C 202, s. 389. Zob. K. Kowalik-Bańczyk [w:] Karta praw podstawowych Unii Europejskiej, 
i sprawiedliwego (uczciwego, słusznego ${ }^{14}$ ) rozpatrzenia swojej sprawy $\mathrm{w}$ rozsądnym terminie przez instytucje, organy i jednostki organizacyjne Unii. Wypowiedź tę powtórzył niemal dosłownie ReNEUAL w art. 3 ust. 1 Księgi III ${ }^{15}$. Ponadto w preambule zasad modelowych Księgi I wskazano na konieczność uwzględnienia w toku interpretacji tych zasad, w szczególności zasady sprawiedliwości.

Wskazując na standardy postępowania administracyjnego w sprawach indywidualnych, tworzących ramy sprawiedliwego przygotowania i wydania decyzji administracyjnej, należy mieć na myśli zinstytucjonalizowaną postać rozpatrywania spraw administracyjnych, przebiegającą według określonych reguł. Z tego punktu widzenia chodzi o pytanie, $w$ jakiej formie dochodzi do rozstrzygania sprawy; w jaki sposób dochodzi do gromadzenia informacji, wymiany argumentacji i podejmowania decyzji, która pozwala uznać wynik zastosowania procedury za sprawiedliwy. Kryterium sprawiedliwości zapadłej decyzji staje się w tym ujęciu sama procedura ${ }^{16}$. Pytając o sprawiedliwą procedurę administracyjną zmierzającą do wydania decyzji, należy odwołać się do „wewnętrznych” wartości tej procedury, które są niezbędne do oceny zarówno prawidłowości ustanowionych reguł prawa procesowego, jak i wzorca należnego zachowania przez stosujące je organy ${ }^{17}$. Obecnie nie powinna już budzić wątpliwości prawdziwość tezy, że prawo nie posiada jedynie formalnej treści, lecz treść rzeczywistą - tzn. zdeterminowaną przez wartości ${ }^{18}$. Owe wartości podlegają normatywiza$\mathrm{cji}^{19}{ }^{19}$, wyrażane są poprzez zasady prawa, które podlegają współstosowaniu

A. Wróbel (red.), Warszawa 2013, s. 1093 i n.; M. Niedźwiedź [w:] System Prawa Administracyjnego, t. 3, Europeizacja prawa administracyjnego, R. Hauser, Z. Niewiadomski, A. Wróbel (red.), Warszawa 2014, s. 747 i n.

14 Nie wdając się w szczegóły, wypadnie jedynie wspomnieć, że „słuszność” (ang. equity) w najbardziej ogólnym znaczeniu w anglosaskiej jurysprudencji utożsamiana jest ze sprawiedliwym potraktowaniem danego podmiotu przez instytucje władzy publicznej - zob. R. Scruton, A Dictionary of Political Thought, London 1996, s. 153.

15 P. Craig, G. della Cananea, O. Mir, J.-P. Schneider, V.M. Tünsmeyer, M. Wierzbowski [w:] ReNEUAL. Model kodeksu..., s. 78 i 102.

16 J. Rawls, A Theory of Justice, Oxford 1971, s. 83, za: Z. Kmieciak, Zarys teorii postępowania administracyjnego, Warszawa 2014, s. 95.

17 Zob. Z. Kmieciak, Zarys..., s. 975-101. Zob. również: L.L. Fuller, Moralność prawa, Warszawa 2004, passim.

18 R. Summers, Instrumentalism and American Legal Theory, Ithaca-London 1982, s. 41: „Rules or other forms of law are not merely formal receptacles but have substantive content (...) its content is necessairly determined by values". Ponadto zob. R. Summers, The Jurisprudence of Law's Form and Substance. Collected Essays in LawHampshire-Vermont 2000, passim; idem, Form and Function in a Legal System, New York 2006, s. 17 i n.; A. Marmor, Positive Law and Objective Values, Oxford 2001, s. 160 i n.; M. Martin, Judging Positivism, Oxford 2014, passim.

19 J. Boć, P. Lisowski, Normatywizacja wartości w prawie administracyjnym [w:] Wartości w prawie administracyjnym, J. Zimmermann (red.), Warszawa 2015, s. 19 i n. 
wraz z regułami prawnymi ${ }^{20}$. Taką normą-zasadą jest sprawiedliwość, której proceduralna treść kształtuje w postępowaniu administracyjnym podstawowe standardy (gwarancje) odnoszące się przede wszystkim do ochrony praw jednostki w toku przygotowania oraz wydania decyzji ${ }^{21}$. Dzięki tym standardom przebieg oraz rezultat postępowania powinny być w odczuciu społecznym odbierane jako sprawiedliwe.

Zasada sprawiedliwości obejmuje elementarne z punktu widzenia praw jednostki założenie odnoszące się do gwarancji proceduralnych. Otóż w oczekiwaniach społecznych pojawia się wymaganie, by rozstrzygnięcia o tym, czy jakieś działanie było w danej sytuacji sprawiedliwe, były dokonywane w sposób zinstytucjonalizowany, to znaczy przez określone podmioty do tego zadania powołane i działające w sposób ujęty w pewne prawidła proceduralne. W piśmiennictwie wskazuje się, że jakkolwiek reguły proceduralne rozstrzygania w sposób zinstytucjonalizowany problemów dotyczących sprawiedliwego rozdziału dóbr i wymiany świadczeń mają z założenia tylko doniosłość wtórną i instrumentalną, faktycznie mogą mieć decydującą doniosłość społeczną ${ }^{22}$. Z jednej strony wymóg ten dotyczy zinstytucjonalizowanej formy przygotowywania i wydawania decyzji administracyjnych, $\mathrm{z}$ drugiej zaś strony odnosi się do konieczności istnienia sądowej kontroli działalności administracji publicznej, która powinna gwarantować badanie nie tyle legalności, co raczej sprawiedliwego procedowania organów administracyjnych. Sądowa kontrola pozostaje wprawdzie poza projektem jednolitego kodeksu postępowania administracyjnego Unii Europejskiej, jednak należy do standardów europejskiej kultury prawnej ${ }^{23}$.

Trybunał Sprawiedliwości Unii Europejskiej podkreślał wielokrotnie w swoim orzecznictwie, że ze sprawiedliwością proceduralną w postępowaniu administracyjnym związane są takie zasady prawa europejskiego, jak m.in.: zasada partycypacji, wymóg uzasadniania aktu administracyjnego

20 Według rozróżnienia norm zaproponowanego przez R. Dworkina - zob. R. Dworkin, Biorac prawa poważnie, Warszawa 1998, passim; idem, A Matter of Principle, Cambridge-London 2000, passim; M. Dybowski, Ronalda Dworkina koncepcja zasad prawa, „Ruch Prawniczy, Ekonomiczny i Socjologiczny” 2001, z. 3, s. 99 i n.

21 M. Fromont, Rechtsschutz gegenüber der Verwaltung in Deutschland, Frankreich und den Europäischen Gemeinschaften, Köln-Berlin-Bonn-München 1967, s. 17.

22 Z. Ziembiński, O pojmowaniu sprawiedliwości, Lublin 1992, s. 176-177.

23 H.C.H. Hofmann, General Principles of EU Law and EU Administrative Law [w:] European Union Law, C. Barnard, S. Peers (eds.), Oxford 2014, s. 219; G. della Cananea, C. Franchini, I Principi dell'Amministrazione Europea, Torino 2013, s. 299; R. Bieber, F. Maiani, Précis de droit européen, Berne 2011, s. 117; A. Skoczylas, Modele uprawnień orzeczniczych sądów administracyjnych w Europie, „Państwo i Prawo” 2012, z. 10, s. 21 i n.; Z. Kmieciak, Europejskie standardy prawa do sadu w sprawach $z$ dziedziny administracji publicznej [w:] System Prawa Administracyjnego, t. 3..., s. 398; W. Piątek, P. Ostojski, Orzeczenie sądu administracyjnego jako podstawa odpowiedzialności administracji publicznej w Polsce i w Niemczech [w:] Odpowiedzialność administracji $i$ w administracji, Warszawa 2013, s. 95. 
czy prawo do wglądu w akta sprawy administracyjnej ${ }^{24}$. Ponadto w doktrynie prawa wskazuje się na funkcjonowanie takich europejskich standardów proceduralnych, jak: zasada praworządności, zakaz samowoli oraz zasada proporcjonalności, prawo do bezstronnego postępowania, prawo do wydania rozstrzygnięcia w rozsądnym terminie, prawo do wysłuchania przed dokonaniem ingerencji w sferę prawną jednostki, prawo dostępu do dokumentów (swobodny dostęp do informacji), zobowiązanie organu do pisemnego uzasadnienia rozstrzygnięcia, obowiązek pouczenia o środkach zaskarżenia, obowiązek ogłoszenia zainteresowanemu treści rozstrzygnięcia oraz ogólny obowiązek urzędników działania w sposób prawidłowy i odpowiedzialny ${ }^{25}$.

\section{Standardy postępowania administracyjnego według przepisów ogólnych Modelu}

Standardy procedury przygotowania i wydania decyzji należy rozumieć $\mathrm{w}$ pierwszej kolejności jako postępowanie zgodne - w ujęciu generalnym - $\mathrm{z}$ zachowaniem: zasady praworządności (ang. the rule of law), prawa do dobrej administracji (ang. the right to good administration) oraz innych zasad związanych z prawem administracyjnym Unii (zob. zdanie I preambuły Księgi I). Owe inne zasady prawa administracyjnego UE zostały w zasadniczej mierze określone w preambule Księgi I Modelu. Chodzi tu zarówno o inne ogólne zasady prawa (m.in. zasadę proporcjonalności, zasadę ochrony uzasadnionych interesów), europejskie prawa podstawowe (np. zasadę równego traktowania i niedyskryminacji), jak i gwarancje skutecznej ochrony prawnej ${ }^{26}$. Z kolei wyrażone w art. 41 Karty praw podstawowych UE prawo do dobrej administracji - postrzegane w literaturze

24 Zob. analizę orzecznictwa TSUE dokonaną przez J. Schwarze: Rechtsstaatliche Grundsätze des Verwaltungsverfahrens [w:] Europäisches Verwaltungsrecht. Enstehung und Entwicklung im Rahmen der Europäischen Gemeinschaft, Baden-Baden 1988, s. 1146 i n. Ponadto zob. W. Cremer, Der Einfluss des Europarechts auf die Gestaltung des Verwaltungsverfahrens in den Mitgliedstaaten [w:] Verwaltung unter dem Einfluss des Europarechts, W. Erbguth, J. Masing (Hrsg.), Stuttgart-München-Hannover-Berlin-Dresden 2006, s. 220.

25 E. Schmidt-Aßmann, Gemeineuropäische Verfahrensprinzipien [w:] Grundlagen des Verwaltungsrechts. Band II. Informationsordnung-Verwaltungsverfahren-Handlungsformen, W. Hoffmann-Riem, E. Schmidt-Aßmann, A. Voßkuhle (Hrsg.), München 2008, s. 489-490.

26 J.P. Terhechte [w:] Verwaltungsrecht der Europäischen Union, J.P. Terhechte (Hrsg.), Baden-Baden 2011, s. 63. Zob. ponadto: H.C.H. Hofmann, G.C. Rowe, A.H. Türk, Administrative Law and Policy of the European Union, Oxford 2011, rozdz. 11; J. Schwarze, Rechtsstaatliche Grundsätze des Verwaltungsverfahrens..., s. 1135 i n.; S. Kadelbach, Allgemeines Verwaltungsrecht unter europäischem Einfluss, Tübingen 1999, s. 406 i n.; T. von Danwitz, Verwaltungsrechtliches System und Europäische Integration, Tübingen 1996, s. 279 i n. 
jako zbiór zasad specyficzny dla postępowania administracyjnego ${ }^{27}$ - obejmuje zasady takie jak: prawo do rzetelnego postępowania, wspomniane już zasady partycypacji (prawa do bycia wysłuchanym) ${ }^{28}$, prawo dostępu do informacji o postępowaniu i dostępu do akt sprawy ${ }^{29}$, zasadę przejrzystości (transparencji) ${ }^{30}$, wolność od samooskarżania się $e^{31}$ oraz obowiązek uzasadnienia rozstrzygnięcia ${ }^{32}$. Ponadto, zgodnie $\mathrm{z}$ art. 41 ust. 1 Karty praw podstawowych UE, każdy ma prawo do tego, by jego sprawa została rozpoznana $\mathrm{w}$ rozsądnym terminie $\mathrm{i}$ bez zwłoki. Natomiast w orzecznictwie Trybunału Sprawiedliwości UE została ukształtowana i utrwalona zasada obowiązku organów w zakresie prawidłowego i zupełnego dochodzenia faktów relewantnych dla rozstrzygnięcia sprawy ${ }^{33}$.

Niezależnie od powyższego $\mathrm{w}$ preambule zasad modelowych Księgi I ReNEUAL wskazano, że władze publiczne powinny mieć na względzie skuteczność (ang. efficiency), efektywność (ang. effectivenes) i zorientowanie na służbę publiczną (ang. service orientation). Należy zwrócić uwagę, że obowiązki władz publicznych w tym zakresie mają związek z podwójną funkcją zasad prawa o postępowaniu administracyjnym (ang. double functional principles), określanych niekiedy w piśmiennictwie niemieckojęzycznym jako „trzecia grupa zasad europejskiego prawa administracyjnego" ${ }^{34}$. Zasady te służą zarówno ochronie obywatela, jak i Unii ${ }^{35}$. W dok-

27 H.P. Nehl, Europäisches Verwaltungsverfahren und Gemeinschaftsverfassung. Eine Studie gemeinschaftsrechtlicher Verfahrensgrundsätze unter besonderer Berücksichtigung "mehrstufiger" Verwaltungsverfahren, Berlin 2002, s. 178 i n.; K. Pfeffer, Das Recht auf eine gute Verwaltung, Baden-Baden 2006, s. 113 i n., 138 i n.; O. Mader, Verteidigungsrechte im Europäischen Gemeinschaftsverwaltungsverfahren, Baden-Baden 2006, s. 134 i n., 264.

28 P. Korzeniowski, Prawne aspekty ochrony środowiska [w:] Prawo administracyjne materialne, Z. Duniewska, B. Jaworska-Dębska, M. Stahl (red.), Warszawa 2014, s. 587.

29 Zob. R. Geiger [w:] European Union Treaties, R. Geiger, D.-E. Khan, M. Kotzur (eds.), München 2015, s. 43 i n.

30 M. Kotzur [w:] European Union Treaties..., s. 1091; H.-P. Folz [w:] Europäisches Unionsrecht, Ch. Vedder, W.H. von Heinegg (Hrsg.), Baden-Baden 2012, s. 1158 i n.

31 A. von Arnauld [w:] Verwaltungsrecht der Europäischen Union..., s. 116. Ponadto zob. R. Bieber, A. Epiney, M. Haag, Die Europäische Union. Europarecht und Politik, Baden-Baden 2013, s. 239-240 - i powołana tam literatura; P. Craig, UK, EU and Global Administrative Law. Foundations and Challenges, Oxford 2016, s. 156 i n.

32 Zob. C. Franchini, European Principles Governing National Administrative Proceedings, „Law and Contemporary Problems” 2004, no. 68, 183-196; M. Ruffert, Von der Europäisierung des Verwaltungsrechts zum Europäischen Verwaltungsverbund, „Die Öffentliche Verwaltung” 2007, s. 761 i n.; M. Klatt [w:] Europäisches Unionsrecht. Band 1, H. von Groeben, J. Schwarze, A. Hatje (Hrsg.), Baden-Baden 2015, s. 788-789.

33 Zob. S. Wittkopp, Sachverhaltsermittlung im Gemeinschaftsverwaltungsrecht. Eine Untersuchung zu den Einflüssen des europäischen Gemeinschaftsrechts auf die Sachverhaltsermittlung im deutschen Verwaltungsverfahren, Hamburg 1999, passim.

34 A. von Arnauld [w:] Verwaltungsrecht der Europäischen Union..., s. 116.

35 Ibidem. 
trynie i orzecznictwie zwracano wielokrotnie uwagę, że charakterystyczną cechą prawa unijnego jest to, że w wielorakich kontekstach prawa jednostki podlegają swoistej instrumentalizacji w celu lepszej realizacji prawa w państwach członkowskich ${ }^{36}$. Przykładowo zasada transparentności postępowania administracyjnego służy nie tylko interesom jednostki w zakresie bezpieczeństwa prawnego, lecz powinna równocześnie „uruchamiać” jawność jako środek kontroli administracji ${ }^{37}$.

Reasumując, standardy postępowania według przepisów ogólnych ReNEUAL należy utożsamiać z zasadami i regułami postępowania administracyjnego, które $\mathrm{z}$ jednej strony przewiduje funkcjonowanie $\mathrm{w}$ tym postępowaniu wskazanych standardów ochrony praw jednostek, z drugiej zaś strony zakłada skuteczność, efektywność i zorientowanie na służbę publiczną w zakresie działań organów administracji. Należy wspomnieć, że dyskusja na temat równoważenia - najogólniej rzecz ujmując - gwarancji procesowych jednostek z wymogami efektywności działania administracji publicznej toczyła się i toczy w dalszym ciągu na gruncie porządków prawnych państw członkowskich Unii, zarówno w obrębie systemów prawnych Europy kontynentalnej, jak i w państwach o tradycji common law.

\section{Szczegółowe rozwiązania prawne zawarte w Księdze III ReNEUAL}

Instytucje prawne składające się na standardy postępowania administracyjnego występują według ReNEUAL w trzech głównych fazach postępowania zmierzającego do wydania decyzji: na etapie wszczęcia postępowania, dalej $\mathrm{w}$ stadium gromadzenia informacji oraz finalnie w ramach zakończenia postępowania.

Zasada sprawiedliwości proceduralnej na etapie wszczęcia postępowania administracyjnego ma być realizowana poprzez zawiadomienie stron o wszczęciu postępowania $z$ urzędu oraz zapobieganie nadużywaniu przez strony ich praw procesowych. Pierwsze z tych rozwiązań służy ochronie interesów stron, drugie zaś wspieraniu efektywności działań organów administracyjnych. W myśl art. III-5 ReNEUAL wskazane zawiadomienie powinno zawierać m.in.: informacje o powodach wszczęcia postępowania oraz informacje o głównych etapach postępowania, wskazanie organu właściwego do wydania ostatecznej decyzji, wskazanie terminu wydania decyzji oraz informację o dostępnych środkach odwoławczych. Szczególne znaczenie posiada wymóg poinformowania stron o dostępnych środkach odwoławczych już na tym wstępnym etapie postępowania, który jest niezależny od tego, czy organ zakończy postępowaniem wydaniem decyzji, czy

36 Zob. A. Hatje, Loyalität als Rechtsprinzip in der Europäischen Union, Tübingen 2007, s. 52 i n.

37 A. von Arnauld, Rechtssicherheit: perspektivische Annäherungen an eine idée directrice des Rechts, Tübingen 2006, s. 460 i n.; idem [w:] Verwaltungsrecht der Europäischen Union..., s. 117 i powołana tam literatura. 
też z powodu określonych przeszkód nie dojdzie do jej wydania. Równie ważny jest wymóg poinformowania strony o powodach wszczęcia postępowania, który posiada podstawowe znaczenie dla zagwarantowania stronie prawa do obrony (art. III-23 ust. 3) ${ }^{38}$. Z kolei w postępowaniach wszczynanych na wniosek twórcy Modelu przewidzieli mechanizm mający eliminować konieczność wszczynania postępowań wskutek składania wniosków bezcelowych lub oczywiście bezzasadnych. W myśl art. III-6 ust. 3 zdanie czwarte tego typu wnioski mogą zostać odrzucone jako niedopuszczalne za pomocą krótko uzasadnionego potwierdzenia otrzymania. Natomiast nie wymaga się wysłania potwierdzenia otrzymania w przypadku, gdy kolejne wnioski składane przez tego samego wnioskodawcę są uważane za nadużycie z uwagi na ich powtarzający się charakter.

Dla sposobu ukształtowania podstaw wydania decyzji istotne znaczenie ma sprawiedliwe procesowanie organów administracji w fazie postępowania wyjaśniającego ${ }^{39}$. Według projektu w stadium tym ma miejsce zarówno postępowanie dowodowe, jak i inspekcja (kontrola). W ramach przepisów mających regulować tę fazę postępowania zasada sprawiedliwości znajduje urzeczywistnienie zwłaszcza poprzez przyznanie stronom różnorodnych uprawnień składających się na prawo do obrony. Wzmocnieniem efektywności działań organu w obszarze zbierania informacji istotnych dla rozstrzygnięcia sprawy są instrumenty prawnoprocesowe przyznane organowi oraz obowiązek współpracy stron. Katalog ogólnych praw stron, które organ powinien respektować $\mathrm{w}$ toku postępowania, został zawarty w treści art. III-8 ust. 1. Spośród nich na szczególne uwzględnienie zasługują: uprawnienie stron do otrzymania odpowiedzi na wszelkie pytania związane z postępowaniem w szybki, przejrzysty i zrozumiały sposób oraz bycia powiadomionym o wszelkich czynnościach proceduralnych i decyzjach, prawo do bycia reprezentowanym przez adwokata lub inną wybraną osobę posiadającą zdolność prawną (w świetle prawa krajowego), a także uprawnienie do ponoszenia tylko takich kosztów, które są uzasadnione i proporcjonalne do kosztów danego postępowania ${ }^{40}$. W ramy powyższych ogólnych uprawnień procesowych wpisują się bardziej szczegółowe prawa i obowiązki stron oraz organu związane $z$ gromadzeniem informacji. Należy zauważyć, że proponowana regulacja dotycząca inspekcji przewiduje daleko idące uprawnienia organów (m.in. prawo żądania wyjaśnień, po-

38 P. Craig, G. della Cananea, O. Mir, J.-P. Schneider, V.M. Tünsmeyer, M. Wierzbowski [w:] ReNEUAL. Model kodeksu..., s. 127-128.

$39 \mathrm{~W}$ języku angielskim wyrażenie gathering of informations oznacza w istocie "gromadzenie informacji”; zob. http://www.reneual.eu/images/Home/BookIII-Single_CaseDecision-Making_individualized_final_2014-09-03.pdf (dostep: 4.09.2019).

40 Zob. J.-P. Schneider, Strukturen und Typen von Verwaltungsverfahren [w:] Grundlagen des Verwaltungsrechts. Band II. Informationsordnung-Verwaltungsverfahren-Handlungsformen, W. Hoffmann-Riem, E. Schmidt-Aßmann, A. Voßkuhle (Hrsg.), München 2008, s. 550 i n. 
bierania próbek, zajmowania dokumentów, plombowania pomieszczeń), które mają stworzyć realne możliwości skutecznego pozyskiwania informacji przez organy przygotowujące decyzje. $\mathrm{W}$ projekcie zastrzeżono przy tym obowiązek organów zapewnienia działania zgodnie z prawem Unii, a w szczególności z poszanowaniem Karty praw podstawowych oraz norm dotyczących ochrony danych osobowych (art. III-17).

Szczególną rolę z punktu widzenia sprawiedliwego rozstrzygnięcia sprawy odgrywają standardy gwarantujące prawo stron dostępu do akt postępowania oraz dotyczące prawa do wysłuchania. W obowiązującym stanie prawnym analizowane uprawnienia znajdują wyraz $\mathrm{w}$ postanowieniach art. 41 ust. 2 lit. a i b Karty praw podstawowych. Brzmienie art. III-22 i III-23 Modelu nie tylko odpowiada standardom wypływającym w tym zakresie z obowiązujących aktów prawa unijnego, lecz uwzględnia reguły ukształtowane w orzecznictwie Trybunału Sprawiedliwości UE.

W stadium wydania decyzji na szczególne podkreślenie z punktu widzenia zasad sprawiedliwości proceduralnej zasługuje obowiązek uzasadnienia decyzji, który obok szeregu wspomnianych powyżej reguł należy do standardów związanych z prawem do dobrej administracji (art. 41 ust. 2 lit. c KPP). Z treści art. III-29 ust. 1 wynika, że organ administracji publicznej podaje powody swojej decyzji w sposób jasny, prosty i zrozumiały. Wymogi te powinny umożliwić stronom zrozumienie toku rozumowania organu, który wydał decyzję, zaś właściwemu sądowi powinny dać sposobność kontroli sądowej. Co istotne, projekt nie przewiduje żadnego wyjątku od rygoru uzasadnienia decyzji, a ponadto nakazuje poinformowanie jej adresata nie tylko o możliwości odwołania w trybie administracyjnym, jeśli taka istnieje, ale i o możliwości zaskarżenia decyzji do sądu oraz o ewentualnym środku prawnym kierowanym do Rzecznika Praw Obywatelskich (art. III-30).

\section{Podsumowanie}

ReNEUAL należy pojmować jako podsumowanie wspólnego dorobku państw europejskich w obszarze administracyjnego prawa procesowego. W literaturze niemieckiej wskazuje się, że europejskie prawo administracyjne posiada swoje źródło nie w doskonałych projektach systemowych, lecz w zebraniu regulacji prawnych poszczególnych dziedzin prawa administracyjnego ${ }^{41}$.

41 K. Rennert, ReNEUAL-Musterentwurf..., s. 69; M. Ruffert, Verwaltungsrecht im Europäischen Verwaltungsverbund, „Die Verwaltung” 2015 (48), No. 4, s. 547 i n.; A. von Bogdandy, Verwaltungsrecht im europäischen Rechtsraum [w:] Handbuch Ius publicum Europaeum. Band IV. Verwaltungsrecht im Europ: Wissenschaft, A. von Bogdandy, S. Cassese, P.H. Huber (Hrsg.), Heidelberg 2011, s. 23. Ponadto zob. T. Groß, Zum Stand der Verwaltungsrechtsvergleichung in Europa: Grundlagen, „Die Verwaltung” 
Zdefiniowanie pojęcia sprawiedliwości (ang. fairness), wyrażonego w art. 41 ust. 1 Karty praw podstawowych i powtórzonego w art. 3 ust. 1 Księgi III ReNEUAL, pozwala na syntezę dorobku prawnoprocesowego w dziedzinie administracji publicznej. Sprawiedliwość proceduralna stanowi expressum standardów postępowania administracyjnego, wyrażających swoiste wartości o charakterze „wewnętrznym” tej procedury. W tej nadrzędnej zasadzie prawa znajdują swoje źródło konkretne reguły Modelu kodeksu postępowania administracyjnego UE. Cała Księga III służy urzeczywistnianiu podstawowego prawa do dobrej administracji w zakresie przygotowania decyzji w sprawach indywidualnych ${ }^{42}$. Sprawiedliwość według ReNEUAL oznacza takie ukształtowanie zasad i reguł postępowania administracyjnego, które $\mathrm{z}$ jednej strony przewiduje funkcjonowanie $\mathrm{w}$ tym postępowaniu wskazanych standardów ochrony praw jednostek, z drugiej zaś daje gwarancje skuteczności, efektywności i zorientowania na służbę publiczną w zakresie działań organów administracji.

Europejskie standardy współczesnego postępowania administracyjnego zawarte są $\mathrm{w}$ zasadach prawa właściwych europejskiej kulturze prawnej, które mają swoje źródło w konstytucjach narodowych i prawie o postępowaniu administracyjnym państw członkowskich Unii. Według tych wzorców w przestrzeni prawa europejskiego wypracowanie standardów sprawiedliwości proceduralnej nastąpiło w orzecznictwie Trybunału Sprawiedliwości UE. Źródłem zasad modelowych są także regulacje szczegółowe prawa europejskiego. ReNEUAL nie eliminuje tych szczegółowych norm, lecz przewiduje współstosowanie (uwzględnianie) postanowień projektu z owymi szczegółowymi przepisami prawa europejskiego. Innymi słowy, uzasadnione jest spostrzeżenie, że twórcy projektu zebrali, usystematyzowali i udoskonalili w omawianym projekcie dotychczas wypracowane standardy postępowań administracyjnych państw członkowskich ${ }^{43}$.

$\mathrm{Z}$ perspektywy polskiego krajowego porządku prawnego Model jest w przypadku wielu rozwiązań innowacyjny. $\mathrm{W}$ zakresie instytucji związanych $\mathrm{z}$ wszczęciem postępowania szczególne znaczenie mają takie rozwiązania, jak obowiązek wskazania przez organ już w zawiadomieniu stron o wszczęciu postępowania z urzędu dostępnych środków odwoławczych (art. III-5 ust. 3), a także możliwość wydania przez organ opinii na temat informacji, które mają być dostarczone przez wnioskodawcę (art. III-13 ust. 2). Z punktu widzenia efektywnego wszczynania postępowań administracyjnych nowatorski charakter posiada niewątpliwie dopuszczalność odrzucania bezcelowych lub oczywiście bezzasadnych wniosków (art. III-6

2012 (45), No. 2, s. 251 i n.; E. Schmidt-Aßmann, Zum Stand der Verwaltungsrechtsvergleichung in Europa: Wissenschaft, „Die Verwaltung” 2012 (45), No. 2, s. 264 i n.

42 P. Craig, G. della Cananea, O. Mir, J.-P. Schneider, V.M. Tünsmeyer, M. Wierzbowski [w:] ReNEUAL. Model kodeksu..., s. 78 i 102.

43 J.-P. Schneider, H.C.H. Hofmann, J. Ziller, Die ReNEUAL Model Rules 2014: Ein Verwaltungsverfahrensrecht für Europa, „Juristen Zeitung” 2015, No. 6 (70), s. 265. 
ust. 3). Natomiast w obszarze gromadzenia informacji nowatorskim rozwiązaniem jest przyjęcie w ramach regulacji ogólnej Modelu możliwości przeprowadzania inspekcji (art. III-16 i n.). Na etapie wydania decyzji administracyjnej istotne znaczenie ma ujęcie expressis verbis wymogu uzasadnienia decyzji w sposób jasny, prosty i zrozumiały, a także pouczenie w decyzji (nieostatecznej) o możliwości zaskarżenia tej decyzji nie tylko w trybie administracyjnym, ale i sądowym oraz do Rzecznika Praw Obywatelskich.

Opracowanie ReNEUAL jest niewątpliwym efektem konwergencji nie tylko samych rozwiązań prawnych państw członkowskich UE w płaszczyźnie administracyjnego prawa procesowego, ale również - a może nade wszystko - europejskiej myśli administracyjnoprawnej. Jego opublikowanie może otworzyć drogę do przenikania poszczególnych jego instytucji do krajowych regulacji postępowania administracyjnego. Z pewnością opracowanie Modelu wpłynęło też na treść projektu rozporządzenia Parlamentu Europejskiego i Rady w sprawie otwartej, efektywnej i niezależnej administracji europejskiej, stanowiącego załącznik do projektu rezolucji Parlamentu Europejskiego z dnia 9 czerwca 2016 r. ${ }^{44}$

\section{Bibliografia}

Arnauld A. von, Rechtssicherheit: perspektivische Annäherungen an eine idée directrice des Rechts, Tübingen 2006.

Bieber R., Maiani F., Précis de droit européen, Berne 2011.

Bieber R., Epiney A., Haag M., Die Europäische Union. Europarecht und Politik, Baden-Baden 2013.

Boć J., Lisowski P., Normatywizacja wartości w prawie administracyjnym [w:] Wartości w prawie administracyjnym, J. Zimmermann (red.), Warszawa 2015.

von Bogdandy A., Verwaltungsrecht im europäischen Rechtsraum [w:] Handbuch Ius publicum Europaeum. Band IV. Verwaltungsrecht im Europ: Wissenschaft, A. von Bogdandy, S. Cassese, P.H. Huber (Hrsg.), Heidelberg 2011.

Cananea G., Franchini C., I Principi dell'Amministrazione Europea, Torino 2013.

Craig P., UK, EU and Global Administrative Law. Foundations and Challenges, Oxford 2016

Cremer W., Der Einfluss des Europarechts auf die Gestaltung des Verwaltungsverfahrens in den Mitgliedstaaten [w:] Verwaltung unter dem Einfluss des Europarechts, W. Erbguth, J. Masing (Hrsg.), Stuttgart-München-Hannover-BerlinDresden 2006.

Danwitz T. von, Verwaltungsrechtliches System und Europäische Integration, Tübingen 1996.

Dworkin R., Biorąc prawa poważnie, Warszawa 1998.

Dworkin R., A Matter of Principle, Cambridge-London 2000.

44 Resolution on an open, efficient and independent European Union administration 2016/2610(RSP), http://www.europarl.europa.eu (dostęp: 25.11.2018). 
Dybowski M., Ronalda Dworkina koncepcja zasad prawa, „Ruch Prawniczy, Ekonomiczny i Socjologiczny" 2001, z. 3.

European Union Treaties, R. Geiger, D.-E. Khan, M. Kotzur (eds.), München 2015.

Europäisches Unionsrecht. Band 1, Ch. Vedder, W.H. von Heinegg (Hrsg.), Baden-Baden 2012.

Europäisches Unionsrecht. Band 1, H. von Groeben, J. Schwarze, A. Hatje (Hrsg.), Baden-Baden 2015.

Franchini C., European Principles Governing National Administrative Proceedings, "Law and Contemporary Problems” 2004, no. 68.

Fromont M., Rechtsschutz gegenüber der Verwaltung in Deutschland, Frankreich und den Europäischen Gemeinschaften, Köln-Berlin-Bonn-München 1967.

Fuller L.L., Moralność prawa, Warszawa 2004.

Groß T., Zum Stand der Verwaltungsrechtsvergleichung in Europa: Grundlagen, „Die Verwaltung” 2012 (45), No. 2.

Hatje A., Loyalität als Rechtsprinzip in der Europäischen Union, Tübingen 2007.

Hofmann H.C.H., Rowe G.C., Türk A.H., Administrative Law and Policy of the European Union, Oxford 2011.

Hofmann H.C.H., General Principles of EU Law and EU Administrative Law [w:] European Union Law, C. Barnard, S. Peers (eds.), Oxford 2014.

Kadelbach S., Allgemeines Verwaltungsrecht unter europäischem Einfluss, Tübingen 1999.

Kawka I., Gospodarcza działalność usługowa w prawie polskim w świetle unijnych swobód przedsiębiorczości i świadczenia usług, Warszawa 2015.

Kmieciak Z., Postępowanie administracyjne i sadowoadministracyjne a prawo europejskie, Warszawa 2010.

Kmieciak Z., Europejskie standardy prawa do sadu w sprawach $z$ dziedziny administracji publicznej [w:] System Prawa Administracyjnego, t. 3, Europeizacja prawa administracyjnego, R. Hauser, Z. Niewiadomski, A. Wróbel (red.), Warszawa 2014.

Kmieciak Z., Zarys teorii postępowania administracyjnego, Warszawa 2014.

Korzeniowski P., Prawne aspekty ochrony środowiska [w:] Prawo administracyjne materialne, Z. Duniewska, B. Jaworska-Dębska, M. Stahl (red.), Warszawa 2014.

Kowalik-Bańczyk K. [w:] Karta praw podstawowych Unii Europejskiej, A. Wróbel (red.), Warszawa 2013.

Krawiec G., Europejskie prawo administracyjne, Warszawa 2009.

Mader O., Verteidigungsrechte im Europäischen Gemeinschaftsverwaltungsverfahren, Baden-Baden 2006.

Marmor A., Positive Law and Objective Values, Oxford 2001.

Martin M., Judging Positivism, Oxford 2014.

Meuwese A., Schuurmans Y., Voermans, W., Towards a European Administrative Act, „Review of European Administrative Law” 2009, no. 2.

Nehl H.P., Europäisches Verwaltungsverfahren und Gemeinschaftsverfassung. Eine Studie gemeinschaftsrechtlicher Verfahrensgrundsätze unter besonderer Berücksichtigung „mehrstufiger” Verwaltungsverfahren, Berlin 2002. 
Niedźwiedź M. [w:] System Prawa Administracyjnego, t. 3, Europeizacja prawa administracyjnego, R. Hauser, Z. Niewiadomski, A. Wróbel (red.), Warszawa 2014.

Ossenbühl, F., Verwaltungsverfahren zwischen Verwaltungseffizienz und Rechtsschutzverfahren, „Neue Zeitrschift für Verwaltungsrecht” 1982.

Piątek W., Ostojski P., Orzeczenie sądu administracyjnego jako podstawa odpowiedzialności administracji publicznej w Polsce i w Niemczech [w:] Odpowiedzialność administracji $i$ w administracji, Warszawa 2013.

Pfeffer K., Das Recht auf eine gute Verwaltung, Baden-Baden 2006.

Rawls J., A Theory of Justice, Oxford 1971.

Rennert K., ReNEUAL-Musterentwurf für ein EU-Verwaltungsverfahrensrecht aus der Sicht des BVerwG, „Deutsches Verwaltungsblatt” 2016, H. 2.

Ruffert M., Von der Europäisierung des Verwaltungsrechts zum Europäischen Verwaltungsverbund, „Die Öffentliche Verwaltung” 2007.

Ruffert M., Verwaltungsrecht im Europäischen Verwaltungsverbund, „Die Verwaltung" 2015 (48), No. 4.

Schmidt-Aßmann E., Gemeineuropäische Verfahrensprinzipien [w:] Grundlagen des Verwaltungsrechts. Band II. Informationsordnung-Verwaltungsverfahren-Handlungsformen, W. Hoffmann-Riem, E. Schmidt-Aßmann, A. Voßkuhle (Hrsg.), München 2008.

Schmidt-Aßmann E., Zum Stand der Verwaltungsrechtsvergleichung in Europa: Wissenschaft, „Die Verwaltung” 2012 (45), No. 2.

Schneider J.-P., Strukturen und Typen von Verwaltungsverfahren [w:] Grundlagen des Verwaltungsrechts. Band II. Informationsordnung-Verwaltungsverfahren-Handlungsformen, W. Hoffmann-Riem, E. Schmidt-Aßmann, A. Voßkuhle (Hrsg.), München 2008.

Schneider J.-P., The ReNEUAL Codification Project - Book III [w:] The Model Rules on EU Administrative Procedures: Adjucation, M. Ruffert (ed.), Groningen 2016.

Schneider J.-P., Hofmann H.C.H., Ziller J., Die ReNEUAL Model Rules 2014: Ein Verwaltungsverfahrensrecht für Europa, „Juristen Zeitung” 2015, No. 6 (70).

Schwarze J., Rechtsstaatliche Grundsätze des Verwaltungsverfahrens [w:] Europäisches Verwaltungsrecht. Enstehung und Entwicklung im Rahmen der Europäischen Gemeinschaft, Baden-Baden 1988.

Scruton R., A Dictionary of Political Thought, London 1996.

Skoczylas A., Modele uprawnień orzeczniczych sądów administracyjnych w Europie, „Państwo i Prawo” 2012, z. 10.

Skouris V., Der Musterentwurf eines EU-Verwaltungsverfahrensgesetzes aus der Sicht des Europäischen Gerichtshofs, „Deutsches Verwaltungsblatt” 2016, H. 4.

Summers R., Instrumentalism and American Legal Theory, Ithaca-London 1982.

Summers R., The Jurisprudence of Law's Form and Substance. Collected Essays in Law, Hampshire-Vermont 2000.

Summers R., Form and Function in a Legal System, New York 2006.

Verwaltungsrecht der Europäischen Union, J.P. Terhechte (Hrsg.), Baden-Baden 2011.

Walkila S., Horizontal Effect of Fundamental Rights in EU Law, Groningen 2016.

Wierzbowski M., Hofmann H.C., Schneider J.-P., Ziller J., Auby J.-B., Craig P., Curtin D., della Cananea G., Galetta D.-U., Mendes J., Mir O., Stelkens U., 
ReNEUAL Model kodeksu postępowania administracyjnego Unii Europejskiej, H.C.H. Hofmann, O. Mir, J.-P. Schneider, J. Ziller (red.), Warszawa 2015.

Wittkopp S., Sachverhaltsermittlung im Gemeinschaftsverwaltungsrecht. Eine Untersuchung zu den Einflüssen des europäischen Gemeinschaftsrechts auf die Sachverhaltsermittlung im deutschen Verwaltungsverfahren, Hamburg 1991.

Akty prawne i dokumenty

Karta praw podstawowych Unii Europejskiej, Dz.Urz. UE z 2016 r. C 202, s. 389.

Rezolution (77) 31 on the protection of the individual in relation to the acts of administrative authorities, adopted by the Committee of Ministers on 28 September 1977, Council of Europe, „Information Bulletin on legal activities”, June 1978.

Resolution on an open, efficient and independent European Union administration 2016/2610(RSP), http://www.europarl.europa.eu.

Załącznik do rekomendacji $\mathrm{CM} / \operatorname{Rec}(2007) 7$ of the Committe of Ministers to member states on good administration on 20 Juni 2007 - „Code of good administration".

\section{Streszczenie}

Przedmiotem rozważań $\mathrm{w}$ niniejszym opracowaniu jest analiza instytucji procesowych zawartych w Księdze III - a w niezbędnym zakresie również w Księdze I - ReNEUAL Modelu kodeksu postępowania administracyjnego Unii Europejskiej. Celem analizy będzie ukazanie minimalnych standardów postępowania administracyjnego w państwach członkowskich UE. Standardy te zostaną zobrazowane według kryteriów składających się na pojęcie sprawiedliwości proceduralnej formułowanej w aktach prawa europejskiego. Według orzecznictwa TSUE oraz doktryny europejskiego prawa administracyjnego standardy postępowania prawa europejskiego wyrażone są w zasadach prawa takich jak m.in. zasada partycypacji, wymóg uzasadniania aktu administracyjnego czy prawo do wglądu w akta sprawy administracyjnej. W preambule zasad modelowych Księgi I ReNEUAL wskazano, że władze publiczne powinny mieć na względzie skuteczność (ang. efficiency), efektywność (ang. effectivenes) i zorientowanie na służbę publiczną (ang. service orientation). Cała Księga III służy urzeczywistnianiu podstawowego prawa do dobrej administracji w zakresie przygotowania decyzji w sprawach indywidualnych. Z perspektywy polskiego krajowego porządku prawnego Model jest w przypadku wielu rozwiązań innowacyjny. W zakresie instytucji związanych z wszczęciem postępowania szczególne znaczenie posiadają rozwiązania takie jak obowiązek wskazania przez organ już w zawiadomieniu stron o wszczęciu postępowania z urzędu dostępnych środków odwoławczych (art. III-5 ust. 3), a także możliwość wydania przez organ opinii na temat informacji, które mają być dostarczone przez wnioskodawcę (art. III-13 ust. 2). Z punktu widzenia efektywnego wszczynania postępowań administracyjnych nowatorski charakter ma niewątpliwie dopuszczalność odrzucania bezcelowych lub oczywiście bezzasadnych wniosków (art. III-6 ust. 3). Natomiast w obszarze gromadzenia informacji nowatorskim rozwiązaniem jest przyjęcie w ramach regulacji ogólnej Modelu możliwości przeprowadzania inspekcji (art. III-16 i n.). Na etapie wydania decyzji administracyjnej istotne znaczenie ma ujęcie expressis verbis wymogu uzasadnienia decyzji w sposób jasny, prosty i zrozumiały, a także pouczenie w decyzji 
(nieostatecznej) o możliwości zaskarżenia decyzji nie tylko w trybie administracyjnym, ale i sądowym oraz do Rzecznika Praw Obywatelskich. Opracowanie ReNEUAL jest niewątpliwym efektem konwergencji nie tylko samych rozwiązań prawnych państw członkowskich UE w płaszczyźnie administracyjnego prawa procesowego, ale również - a może nade wszystko - europejskiej myśli administracyjnoprawnej. Jego opublikowanie może otworzyć drogę do przenikania poszczególnych instytucji do krajowych regulacji postępowania administracyjnego. $\mathrm{Z}$ pewnością opracowanie Modelu wpłynęło też na treść projektu rozporządzenia Parlamentu Europejskiego i Rady w sprawie otwartej, efektywnej i niezależnej administracji europejskiej, stanowiącego załącznik do projektu rezolucji Parlamentu Europejskiego z dnia 9 czerwca 2016 r.

Słowa kluczowe: sprawiedliwość proceduralna, postępowanie administracyjne Unii Europejskiej, ochrona praw jednostki w postępowaniu administracyjnym, zasady ogólne postępowania administracyjnego, skuteczność, efektywność, zorientowanie na służbę publiczną

\title{
Standards of Administrative Proceedings under the ReNEUAL Model Rules on EU Administrative Procedure
}

\begin{abstract}
This study aims to analyse the procedural institutions contained in Book III - and as necessary also Book I - of the ReNEUAL Model Rules on EU Administrative Procedure. The objective is to indicate the minimum standards of administrative procedure in EU member states which are illustrated following the criteria that constitute the notion of procedural justice formulated in the acts of European law. According to the case law of the CJEU and the doctrine of European administrative law, procedural standards of European law are expressed in such legal principles as that of participation, the requirement of justifying administrative acts or the right of access to administrative case files. In the preamble of the ReNEUAL model rules to Book I, one reads that public authorities should take into account efficiency, effectiveness and service orientation. The entire Book III serves to enact the basic right to good administration as regards preparation of decisions in individual cases. From the perspective of the national Polish legal order, the Model is innovative in the case of many solutions. As regards institutions related to the lodging of proceedings of particular importance are such solutions as the body's obligation to indicate - already in its notice for the parties of launching ex officio proceedings - available means of appeal (Article III-5(3)) as well as the possibility of its issuance of an opinion on the information to be provided by the applicant (Article III-13 (2)). As regards the effective launch of administrative proceedings, the admissibility of rejecting aimless or clearly ungrounded applications (Article III-6 (3)) are surely innovative. In terms of information collection, an innovative solution is the possibility of inspections in the framework of the general regulation of the Model (Article III-16 ff). At the stage of the issuance of administrative decisions, of considerable importance is the expressis verbis proposal for the requirement of decision justification in a manner that is clear, simple and understandable as well as the instruction contained within the (non-finite) decision that it can be appealed against not just in administrative proceedings but before a court and the Ombudsman. ReNEUAL itself is, unquestionably, a result of the convergence of not just the legal solutions of EU member states
\end{abstract}


in the field of administrative procedural law but also - and possibly above all - the European administrative legal thought. Its publication could pave the way for its individual institutions penetrating national administrative procedure regulations. Further, the Model has certainly had an impact on the contents of the draft regulation of the European Parliament and of the Council for an open, effective and independent European administration, an annex to the European Parliament resolution of 9 June 2016.

Keywords: procedural fairness, administrative procedure of European Union, protect of individual rights in administrative procedure, general principles of administrative procedure, efficiency, effectiveness, service orientation 